\title{
Characterization of the Dual Subcellular Localization of Lilium LsGRP1, a Plant Class II Glycine-Rich Protein
}

\author{
Chia-Hua Lin and Chao-Ying Chen
}

Department of Plant Pathology and Microbiology, National Taiwan University, No. 1, Sec. 4, Roosevelt Rd., Taipei 10617, Taiwan, Republic of China.

Accepted for publication 13 March 2014.

\section{ABSTRACT}

Lin, C.-H., and Chen, C.-Y. 2014. Characterization of the dual subcellular localization of Lilium LsGRP1, a plant class II glycine-rich protein. Phytopathology 104:1012-1020.

The defense-related gene LsGRPl exhibits an increased level of expression in Lilium spp. after being infected by Botrytis elliptica, the fungal pathogen of lily leaf blight. In this study, the expression profile of the LsGRP1 protein (a plant class II glycine-rich protein) was characterized biochemically and its subcellular localization in lily leaves was evaluated using immunohistochemistry, enhanced green fluorescent protein (EGFP) imaging, and protein extraction analysis. Using an LsGRP1-specific antibody, LsGRP1 was found to be most abundant in epidermal cells and phloem tissues. Leaves from lily plants at different growth stages demonstrated similar levels of 14- and 16-kDa LsGRP1 and a decreased amount of 23-kDa LsGRP1 at the senescence stage. LsGRP1-EGFP imaging and protein extraction assays revealed that 14-kDa LsGRP1 was located in the plasma membrane whereas 16- and 23-kDa LsGRP1 was weakly bound to the cell wall. The time course analyses of LsGRP1 expression in response to salicylic acid treatment or B. elliptica infection showed an increased accumulation of 14- and 23-kDa LsGRP1 over time. Because 23-kDa LsGRP1 could be detected by an ubiquitin antibody, conversion of $14-\mathrm{kDa}$ to $23-\mathrm{kDa}$ LsGRP1 via mono-ubiquitination was presumed, which is a phenomenon that has not been reported for a plant class II glycine-rich protein.
Leaf and flower blight, caused by the fungal pathogen Botrytis elliptica (Berkeley) Cooke, is destructive to lily plants worldwide $(6,22)$. The plant hormone salicylic acid (SA) and agrochemical probenazole have been proven to elicit systemic resistance against $B$. elliptica in the Oriental lily cultivar Stargazer (Lilium 'Stargazer') $(3,16,17,18)$. Lilium 'Stargazer' glycine-rich protein 1 (LsGRP1) cDNA cloned from a Stargazer lily that had been predrenched with $\mathrm{SA}$ is predicted to encode a glycine-rich protein (GRP) of 138 amino acids. The expression of LsGRPl increases systemically after inoculation with $B$. elliptica and treatments with SA and probenazole, as indicated by Northern blot analysis $(17,18)$. In addition, SA treatment results in an earlier increased expression of LSGRPI upon B. elliptica infection (17). By using synthetic LsGRP1-derived peptides, the in vitro inhibitory activity of LsGRP ${ }^{\mathrm{C}}$ (corresponding to the C-terminal region of LsGRP1) on different types of phytopathogenic microorganisms via alteration of microbial membrane permeability and induction of fungal programmed cell death-like phenomena were demonstrated. Furthermore, $\mathrm{LsGRP} 1^{\mathrm{C}}$ was shown to be located on the cell surface of fungal species, including B. elliptica (14).

Plant GRP genes are generally expressed in tissue-specific modes and under developmental regulation $(23,26,27)$. Many plant GRPs, which are induced by various biotic and abiotic factors, are involved in plant stress responses $(23,26,27)$. Based on protein structure, plant GRPs are categorized into five classes (19). LsGRP1, which features an N-terminal signal peptide, glycine-rich repeats (GGXXGG), and a C-terminal cysteine-rich domain (17), belongs to the class II GRPs. Two characterized

Corresponding author: C.-Y. Chen: E-mail address: cychen@ntu.edu.tw

* The $\boldsymbol{e}$-Xtra logo stands for "electronic extra" and indicates that Figures 4 and 5 appear in color online.

http://dx.doi.org/10.1094/PHYTO-01-14-0020-R

(c) 2014 The American Phytopathological Society plant class II GRPs (i.e., tobacco cdiGRP and Arabidopsis AtGRP-3) are involved in the activation of plant defense responses. Enhanced accumulation of cadmium-inducing cdiGRP, due to its interaction with GrIP, induced callose deposition in the cell walls of vascular tissues and blocked the systemic movement of Turnip vein-clearing virus $(35,36)$. The SA-inducible AtGRP-3 served as an extracellular ligand to the cell-wall-associated kinase Wak1 and the interaction resulted in defense-related signal transduction $(25,40)$.

In this study, the expression profile of LsGRP1 was determined, its histological distribution and cellular location were characterized, and its interacting proteins were investigated using immunoprecipitation. Based on these results, ubiquitination of LsGRP1, which might be related to dual subcellular localization and represented a new feature for a plant class II GRP, was implicated.

\section{MATERIALS AND METHODS}

Plant materials. Stargazer lily bulbs with a perimeter of 16 to $18 \mathrm{~cm}$ were planted in a potting mix containing BVB Substrate No. 2 (Bas van Buuren, Maasland, Holland), vermiculite, and perlite at a ratio of $6: 1: 1(\mathrm{vol} / \mathrm{vol} / \mathrm{vol})$ and cultured at 18 to $22^{\circ} \mathrm{C}$ and 70 to $80 \%$ relative humidity with a cycle of 16 and $8 \mathrm{~h}$ of light and darkness, respectively.

Pathogen cultivation. B. elliptica B061 was cultured on V8 medium (20\% V8 vegetable juice [Campbell Soup Company, Camden, $\mathrm{NJ}$ ], $0.3 \% \mathrm{CaCO}_{3}$, and $1.5 \%$ agar) at $20^{\circ} \mathrm{C}$ under near UV for 5 to 7 days (17). The conidia of B. elliptica were suspended in $0.05 \%$ Tween-20 solution and adjusted to a final concentration of $5 \times 10^{4}$ conidia $/ \mathrm{ml}$.

Sampling of Stargazer lily tissues for the LsGRP1 expression assay. The spatial expression profile of LsGRP1 was assayed on different tissues (bulb, root, stem, leaf, petal, stamen, and pistil) of 11-week-old flowering lily plants and the temporal expression profile was assayed on the middle leaves of 2-, 4-, 6-, 
8-, 10-, 12-, and 14-week-old plants. Different tissues or the middle leaves of three plants were collected for protein extraction. For the LsGRP1 expression assays after SA treatment and fungal infection, lily plants were drenched with $0.5 \mathrm{mM}$ SA solution or foliar sprayed with $B$. elliptica conidial suspension. The middle leaves from plants drenched with water or sprayed with $0.05 \%$ Tween-20 solution were used as the controls. Three plants were used for each treatment.

Protein extraction, sodium dodecyl sulfate-polyacrylamide gel electrophoresis, and Western blot analysis. Stargazer lily tissue $(1 \mathrm{~g})$ was ground to a fine powder in liquid nitrogen and mixed with $4 \mathrm{ml}$ of protein extraction buffer (EB) $(0.2 \mathrm{M} 3-(\mathrm{N}-$ morpholino)-propanesulfonic acid [MOPS] [pH 7.0], 5\% polyvinyl polypyrrolidone, $1 \%$ Triton $\mathrm{X}-100,10 \%$ glycerol, $2 \%$ 2-methyl-diethyltryptamine, $1 \mathrm{mM}$ phenylmethanesulfonyl fluoride [PMSF], and $1 \times$ proteinase inhibitor cocktail [Sigma-Aldrich, St. Louis, MO]). The supernatant was collected as a protein sample by centrifugation at $15,000 \times g$ and $4^{\circ} \mathrm{C}$ for $10 \mathrm{~min}$. Protein samples were subjected to tricine-sodium dodecyl sulfate-polyacrylamide gel electrophoresis (Tricine-SDS-PAGE) (28) using a $4 \%$ stacking and a 10 or $16 \%$ resolving gel, then transferred to $0.45 \mu \mathrm{m}$ polyvinylidene fluoride (PVDF) membrane (Merck Millipore, Billerica, MA) using Towbin transfer buffer $(25 \mathrm{mM}$ Tris [pH 8.3], $192 \mathrm{mM}$ glycine, and 20\% methanol) at a constant output current of $400 \mathrm{~mA}$ for $120 \mathrm{~min}$. The PVDF membrane with the transferred proteins was washed with distilled water for 5 min, blotted with 5\% skim milk in phosphate-buffered saline (PBS) $\left(137 \mathrm{mM} \mathrm{NaCl}, 2.7 \mathrm{mM} \mathrm{KCl}, 10 \mathrm{mM} \mathrm{Na}_{2} \mathrm{HPO}_{4}\right.$, and $2 \mathrm{mM}$ $\mathrm{KH}_{2} \mathrm{PO}_{4}, \mathrm{pH}$ 7.4) for $1 \mathrm{~h}$, hybridized with primary antibody in PBS containing 5\% skim milk for $1 \mathrm{~h}$, washed with $0.05 \%$ Tween-20 in PBS (PBST) three times for $10 \mathrm{~min}$, hybridized with horseradish peroxidase-conjugated anti-rabbit immunoglobulin $\mathrm{G}$ (IgG) (GE Healthcare, Piscataway, NJ or GeneTex Inc., Irvine, CA) in PBS containing 5\% skim milk for $1 \mathrm{~h}$, then washed with PBST three times for $10 \mathrm{~min}$. The signals of LsGRP1 were generated using Immobilon Western HRP Substrate (Merck Millipore) and analyzed using the GeneGnome5 Chemiluminescent Western Imaging System (Syngene, Cambridge, UK). The primary LsGRP1 $^{\mathrm{N}}$ antibody was produced from a rabbit immunized with chemically synthesized N-terminal partial sequences of the deduced LsGRP1 protein, excluding the signal peptide. The primary ubiquitin antibody that was produced from a rabbit immunized with a synthetic peptide that mapped to a region between residues 1 and 50 of human ubiquitin (Swiss-Prot P62988) was purchased from Novus Biologicals (Littleton, CO).

Co-immunoprecipitation and liquid chromatography/electrospray ionization-tandem mass spectrometry. The middle leaves of a 7-week-old Stargazer lily were sprayed with B. elliptica conidial suspension or $0.05 \%$ Tween-20 solution and collected at 5 days postinoculation (dpi) for co-immunoprecipitation analysis. The leaf tissues $(200 \mathrm{mg})$ from each treatment were ground to a fine powder in liquid nitrogen, mixed with $1 \mathrm{ml}$ of RIPA buffer (25 mM Tris- $\mathrm{HCl}$ [pH 7.3], $150 \mathrm{mM} \mathrm{NaCl}, 2 \mathrm{mM}$ ehylenediaminetetraacetic acid, 5\% glycerol, 1\% Nonidet P-40, $0.5 \%$ sodium deoxycholate, $0.1 \%$ SDS, $1 \mathrm{mM}$ PMSF, and $1 \times$ proteinase inhibitor cocktail [Sigma-Aldrich]) and incubated at $4^{\circ} \mathrm{C}$ with $20 \mathrm{rpm}$ rotation for $2 \mathrm{~h}$. The supernatant was collected by centrifugation at $15,000 \times \mathrm{g}$ and $4^{\circ} \mathrm{C}$ for $30 \mathrm{~min}$ and filtered through a $0.45-\mu \mathrm{m}$ MCE filter (Merck Millipore). LsGRP1 ${ }^{\mathrm{N}}$ antibody was added to the filtrate and incubated at $4^{\circ} \mathrm{C}$ with $20 \mathrm{rpm}$ rotation overnight. The fraction with no added LsGRP1 $1^{\mathrm{N}}$ antibody was used as the negative control. After adding protein A agarose (Fast Flow; Merck Millipore), the mixture was incubated at $4^{\circ} \mathrm{C}$ with $20 \mathrm{rpm}$ rotation for $2 \mathrm{~h}$ and then washed three times with $1 \mathrm{ml}$ of PBS. The proteins that were recovered from the protein A agarose were separated by Tricine-SDS-PAGE in a $16 \%$ acrylamide gel and visualized by silver staining (Silver Stain Plus Kit; Bio-Rad, Hercules, CA). The protein bands were isolated from the gel, digested with trypsin, and assayed using liquid chromatography-electrospray ionization-tandem mass spectrometry (LCESI-MS/MS) (Q Exactive; Thermo Fisher Scientific Inc., Hampton, $\mathrm{NH}$ ). Finally, the MS/MS data were analyzed using the MASCOT search engine (Matrix Science, London) to identify the proteins.

Immunohistochemistry. The middle leaves of a 7-week-old Stargazer lily were cut into $1.5-\mathrm{cm}^{2}$ pieces and immersed in a solution of $1.85 \%$ formaldehyde, $5 \%$ glacial acetic acid, and $50 \%$ ethanol for $12 \mathrm{~h}$. The fixed tissues were dehydrated in a series of solutions as follows: $50 \%$ ethanol, one time; $70 \%$ ethanol, one time; $80 \%$ ethanol, one time; $95 \%$ ethanol, two times; and $100 \%$ ethanol, two times; each for $30 \mathrm{~min}$. Then, the dehydrated tissues were sequentially immersed in Histo-Clear II (National Diagnostics Inc., Charlotte, NC) two times for $30 \mathrm{~min}$, Histo-Clear II/ paraffin (Tissue Embedding Media; Leica, Wetzlar, Germany) mixture $(\mathrm{vol} / \mathrm{vol}=1 / 1)$ at $58^{\circ} \mathrm{C}$ for $1 \mathrm{~h}$, and paraffin at $58^{\circ} \mathrm{C}$ for $1 \mathrm{~h}$. Finally, the leaf tissues were embedded in paraffin and the paraffin blocks containing tissues were cut into $12-\mu \mathrm{m}$ sections using rotary microtomes (RM2235; Leica) before attachment to a $0.1 \%$ poly-L-lysine-precoated slide (Sigma-Aldrich). The tissue sections on slides were dried at $50^{\circ} \mathrm{C}$ for $3 \mathrm{~h}$; deparaffinized twice in xylene for $5 \mathrm{~min}$; and sequentially rehydrated in 100, 95, 80, and $70 \%$ ethanol, each for $5 \mathrm{~min}$. The rehydrated tissues were rinsed in Tris-buffered saline (TBS) $(50 \mathrm{mM}$ Tris- $\mathrm{Cl}$ [pH 7.4] and $150 \mathrm{mM} \mathrm{NaCl}$ ) for $5 \mathrm{~min}$, immersed in $98^{\circ} \mathrm{C}$ Tris-EDTA buffer (10 mM Tris-HCl [pH 9.0], $1 \mathrm{mM}$ EDTA, and 0.05\% Tween-20) for $20 \mathrm{~min}$, and cooled to room temperature for antigen retrieval. The tissues were rinsed in TBS for $5 \mathrm{~min}$, incubated in blocking reagent (TBS containing 5\% bovine serum albumin) for $1 \mathrm{~h}$, hybridized with LsGRP1 ${ }^{\mathrm{N}}$ antibody in blocking reagent for $1 \mathrm{~h}$, washed with TBS containing $0.05 \%$ Tween-20 (TBST) two times for $5 \mathrm{~min}$, incubated in blocking reagent with alkaline phosphatase-conjugated anti-rabbit IgG antibody (Sigma-Aldrich) for $1 \mathrm{~h}$, washed with TBST two times for $5 \mathrm{~min}$, and rinsed with alkaline phosphatase reaction buffer (100 mM Tris [pH 9.5], $100 \mathrm{mM}$ $\mathrm{NaCl}$, and $5 \mathrm{mM} \mathrm{MgC1}{ }_{2}$ ) for $5 \mathrm{~min}$. LsGRP1 was detected using a reagent consisting of $0.48 \mathrm{mM}$ nitro blue tetrazolium and $0.56 \mathrm{mM} 5$-bromo-4-chloro-3-indolyl phosphate in alkaline phosphatase reaction buffer, and the coloration reaction was stopped by washing the tissues with distilled water for $5 \mathrm{~min}$. The stained tissues were observed under a Leica DMR microscope and the images were captured using a Leica DFC490 digital camera system with the XnView software (Kolor, Savoie, France). For the control, preimmune rabbit serum was used instead of LsGRP1 ${ }^{\mathrm{N}}$ antibody.

Subcellular localization of enhanced green fluorescent protein-tagged proteins in onion epidermal cells. The 417-bp open reading frame (ORF) of LsGRP1 was amplified using primer 337 (5'-TAGGATCCATGGCTTCTAAGGCTCTTC-3) and primer 340 (5'-GCAAGCTTTGGGTGTCCATAAGCAGG-3'). The coding sequence of enhanced green fluorescent protein (EGFP) was amplified using primer 341 (5'-GCAAGCTTAGTAAAGGAG AAGAACTTTTCAC-3') and primer 390 (5'-CCGAGCTCTATT TGTATAGTTCATCCATGCC-3'). Then, an LsGRPl-EGFP segment was obtained by in-frame ligation of the LsGRP1 and EGFP amplicons after HindIII digestion. The LsGRPl-EGFP fragment was then used to replace the coding sequence of $\beta$-glucuronidase (GUS) in the binary vector pBI121 (Clontech Laboratories, Inc., Mountain View, CA) after digestion with BamHI and SacI, which resulted in the recombinant plasmid pBI-LsGRP1-EGFP that expressed the LsGRP1-EGFP fusion protein under the control of the constitutive $35 \mathrm{~S}$ promoter. On the other hand, the EGFP amplicon was amplified using primer 389 (5'-CCGGATCCATGAGTAAA GGAGAAGAACTTTTC-3') and primer 390. The EGFP fragment was used to replace the coding sequence of GUS on pBI121 after digestion with $\mathrm{BamHI}$ and $\mathrm{SacI}$, which resulted in the control plasmid pBI-EGFP. After sequence confirmation, the two 
constructs were individually introduced into Agrobacterium tumefaciens strain $\mathrm{C}_{58 \mathrm{C}^{1}}$ (37) by electroporation.

The transient expression of a foreign gene in onion epidermal cells was performed by Agrobacterium-mediated transformation (34). The transformed onion tissues were immersed in MES buffer (10 mM 2-(N-morpholino)ethanesulfonic acid [MES] and $1 \times$ Murashige and Skoog basal salt mixture [MS salts] [PhytoTechnology Laboratories, Mission, KS], pH 5.7) or MOPS buffer (10 mM MOPS and $1 \times$ MS salts, $\mathrm{pH} 7.0$ ) at $25^{\circ} \mathrm{C}$ in the dark for 24 to $48 \mathrm{~h}$, and then examined under a Leica DMR fluorescence microscope that was equipped with an Endow GFP filter set (41017 Endow GFP filter set: band-pass filter of 450 to $490 \mathrm{~nm}$, dichroic mirror of $495 \mathrm{~nm}$, and band-pass filter of 505 to $550 \mathrm{~nm}$; Chroma Technology Co., Brattleboro, VT). The images were captured using a Leica DFC490 digital camera system with the XnView software (Kolor). For plasmolysis, onion epidermal cells were treated with $2 \mathrm{M} \mathrm{NaCl}$ before observation.

Prediction of subcellular localization, membrane protein topology, and ubiquitination site. The putative subcellular localization was analyzed using the ProtComp ver. 9.0 server (http://linux1.softberry.com/berry.phtml). The location of transmembrane domains and the structure of the transmembrane helix were predicted using the SOSUI ver. 1.11 server (http://bp. nuap.nagoya-u.ac.jp/sosui/). The potential ubiquitination sites were analyzed using the CKSAAP_UbSite software (4).

Detergent-assisted protein extraction. The middle leaf tissues of a 7-week-old Stargazer lily were ground to a fine powder in liquid nitrogen. Then, $200 \mathrm{mg}$ of pulverized tissues were extracted with $0.8 \mathrm{ml}$ of $1 \%$ SDS solution and the supernatant was collected as fraction S. The SDS-extracted pellet was washed five times with $0.8 \mathrm{ml}$ of PBS, and the supernatant of the fifth PBS washing was collected as fraction SP. Finally, the pellet was reextracted with $0.8 \mathrm{ml}$ of $1 \%$ SDS solution and the supernatant was collected as fraction SPS.

Another $200 \mathrm{mg}$ of pulverized tissue was extracted with $0.8 \mathrm{ml}$ of PBS, and the supernatant was collected as fraction P. The PBSextracted pellet was washed five times with $1 \mathrm{ml}$ of PBS buffer, and the supernatant of the last PBS washing was collected as fraction PP. The pellet was reextracted with $0.8 \mathrm{ml}$ of $1 \%$ SDS solution, and the supernatant was collected as fraction PPS. All fractions were analyzed by Western blotting, as described above, and the EB-extracted protein sample was used as a positive control.

Extraction of apoplastic proteins. The procedure to extract apoplastic proteins was modified from the methods described by Boudart et al. (2) and Soares et al. (32). The detached middle leaves of a 7-week-old Stargazer lily were washed with deionized water and vacuum-infiltrated with $15 \mathrm{mM}$ acetate buffer $(\mathrm{pH} 4.6)$ two times for $2 \mathrm{~min}$. The apoplastic fluids of the vacuum-infiltrated leaves were collected by centrifugation at $300 \times g$ and $20^{\circ} \mathrm{C}$ for $15 \mathrm{~min}$ with swinging buckets. Then, the leaves were sequentially re-vacuum-infiltrated with $1 \mathrm{M} \mathrm{NaCl}, 0.2 \mathrm{M} \mathrm{CaCl}_{2}$, and $2 \mathrm{M}$ $\mathrm{LiCl}$ in $15 \mathrm{mM}$ acetate buffer $(\mathrm{pH} 4.6)$ and then with $0.05 \mathrm{M}$ 1,2-diaminocyclohexane tetra acetic acid monohydrate (CDTA) in $100 \mathrm{mM}$ acetate buffer ( $\mathrm{pH}$ 5.6). The apoplastic fluid from each re-vacuum-infiltration step was collected by centrifugation at $300 \times g$ and $20^{\circ} \mathrm{C}$ for 15 min with swinging buckets. The malate dehydrogenase (MDH) activity was assayed as a marker of cytosolic contamination using the method described by LópezMillán et al. (15). Only the apoplastic fluids without detectable $\mathrm{MDH}$ activity were dialyzed in deionized water, lyophilized, and analyzed by Western blotting.

Extraction of labile and weakly bound cell wall proteins from isolated cell walls. The procedure to isolate plant cell walls was as described by Feiz et al. (8) and the middle leaves of 7-week-old Stargazer lily plants were used. Proteins were sequentially extracted from the isolated cell walls using $0.2 \mathrm{M}$ $\mathrm{CaCl}_{2}$ and $2 \mathrm{M} \mathrm{LiCl}$ in $15 \mathrm{mM}$ acetate buffer ( $\left.\mathrm{pH} 4.6\right)$ and $0.05 \mathrm{M}$ CDTA in $100 \mathrm{mM}$ acetate buffer (pH 5.6), and the individual, salt-extracted supernatants were dialyzed in deionized water, lyophilized, and analyzed by Western blotting.

Cell wall-degrading enzyme-mediated extraction. Cell walldegrading enzyme-mediated protein extraction was performed by treating the samples with cell wall-degrading enzyme at 250 or $125 \mathrm{ng} / \mathrm{ml}$ for $1 \mathrm{~h}$ or at $100 \mathrm{ng} / \mathrm{ml}$ for 1,2 , or $3 \mathrm{~h}$. The middle leaf tissues $(100 \mathrm{mg})$ that were collected from 6-week-old Stargazer
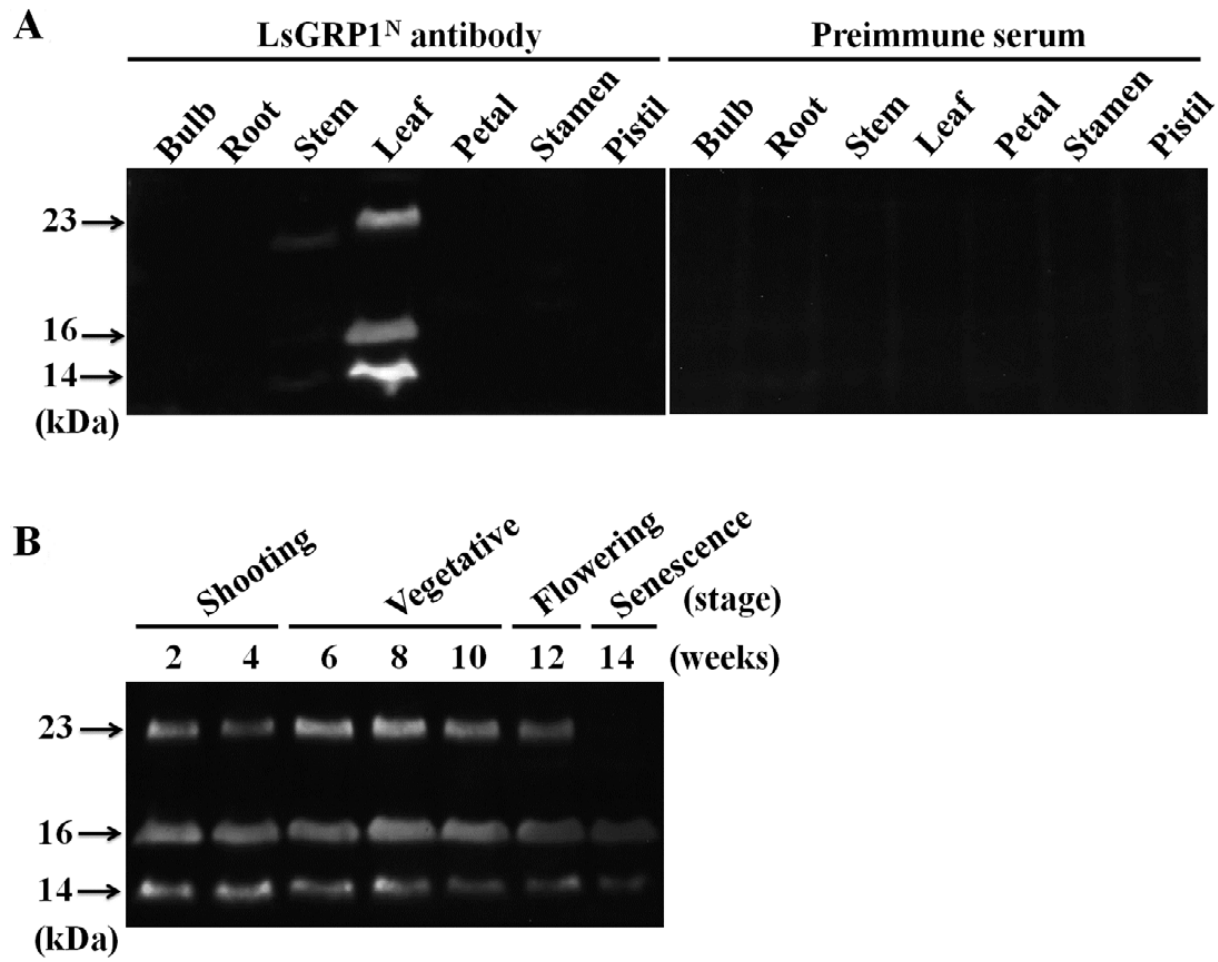

Fig. 1. Spatial and temporal profiles of LsGRP1 expression. Western blot analysis was performed using LsGRP1 ${ }^{\mathrm{N}}$ antibody on A, different organs of 11 -week-old Stargazer lily and $\mathbf{B}$, the middle leaves of different growth stages of Stargazer lily. 
lily plants were pulverized to a fine powder in liquid nitrogen and mixed with $4 \mathrm{ml}$ of $\mathrm{CaCl}_{2}$ buffer $\left(1 \mathrm{mM} \mathrm{CaCl}_{2}, 5 \mathrm{mM}\right.$ MES [pH 5.7], $1 \mathrm{mM}$ PMSF, and $1 \times$ proteinase inhibitor cocktail [SigmaAldrich]) containing pectinase (Sigma-Aldrich) or cellulase (Cellulysin; Merck Millipore). After incubation at room temperature for a period of time, the supernatants were collected by centrifugation at $15,000 \times g$ for $3 \mathrm{~min}$ and analyzed using Western blotting. The control sample was extracted with $\mathrm{CaCl}_{2}$ buffer alone.

\section{RESULTS}

The expression of LsGRP1 specifically in Stargazer leaves. The spatial expression profile of LsGRP1 in Stargazer lily is shown in Figure 1A. As detected by LsGRP1 ${ }^{\mathrm{N}}$ antibody, three LsGRP1 signals of 14,16 , and $23 \mathrm{kDa}$ were observed in the leaves and stems but not in the bulbs, roots, petals, stamens, or pistils of 11-week-old flowering plants. The LsGRP1 signals from leaves were strong, whereas those from the stems were extremely faint and present only in young stem tissues. The leaf specificity of three LsGRP1 signals was also shown in 11-week-old flowering Stargazer lily plants at 5 days after SA treatment or $B$. elliptica inoculation.

The temporal pattern analysis of LsGRP1 expression indicated that 14-, 16-, and 23-kDa LsGRP1 appeared in the leaves of lily at different growth stages, including the shooting, vegetative, flowering, and senescence stages (Fig. 1B). LsGRP1 of 14 and $16 \mathrm{kDa}$ was present at similar levels in all sampled growth stages, whereas the amount of $23-\mathrm{kDa}$ LsGRP1 was slightly higher at the vegetative stage (6- to 8-week-old) but was severely decreased at the senescence stage (14-week-old).

Confirmation of LsGRP1 protein variants by MS/MS analysis. Because two of the three LsGRP1 signals had higher molecular masses than the theoretical $13.76 \mathrm{kDa}$, these LsGRP1 signals were isolated by immunoprecipitation using LsGRP1 ${ }^{\mathrm{N}}$ antibody (Fig. 2A) and identified using LC-ESI-MS/MS analysis (Fig. 2B). The Mascot search results indicated that the three signals of 14, 16, and $23 \mathrm{kDa}$ were identified as LsGRP1 with probability-based Mowse scores of 21, 22, and 24 in $61 \%$ sequence coverage (Fig. $2 \mathrm{~B}$ and $\mathrm{C}$ ). In addition, two putative LsGRP1-interacting proteins (LsIPs) of 10 and $19 \mathrm{kDa}$ were coisolated from diseased and healthy Stargazer leaves, respectively. However, these putative LsIPs could not be identified in the Mascot search.

LsGRP1 is abundant in epidermal and phloem tissues. The distribution of LsGRP1 in the leaf tissues of Stargazer lily was investigated immunohistochemically using $\mathrm{LsGRP}^{\mathrm{N}}$ antibody (Fig. 3). The cross-sections of the leaves revealed that LsGRP1 was most abundant in epidermal and phloem tissues. The darkpurple LsGRP1 signals were distributed unevenly and concentrated in the epidermis, especially in the cuticle and thickened cell walls, and phloem tissues. Moreover, the dark-purple LsGRP1 signals were mainly associated with the outer edges of the cells, indicating the localization of LsGRP1 in the cell wall without excluding the possibility in the plasma membrane.

Dual subcellular localization of LsGRP1 in the plasma membrane and the cell wall. The subcellular localization of LsGRP1 that was predicted by the ProtComp ver. 9.0 server is summarized in Table 1. Significant higher integral scores were given for the plasma membrane (4.86) and extracellular space (3.11) compared with those in other subcellular localizations (0.00 to 0.69$)$. Thus, LsGRP1 was presumed to accumulate in the plasma membrane and/or the extracellular space (including the cell wall), and these results were supported by the immunohistochemistry results (Fig. 3). Furthermore, EGFP imaging in transformed onion epidermal cells that were incubated in MES buffer indicated that LsGRP1EGFP was located on the cell surface, unlike EGFP, which was located in the cytoplasm (Fig. 4). Then, better visualization of the subcellular localization of LsGRP1-EGFP was achieved in plasmolyzed epidermal cells, and the LsGRP1-EGFP signals were found in the plasma membrane. Furthermore, because EGFP fluorescence was quenched at low $\mathrm{pH}$ (10) by incubation in MES buffer, the transformed onion tissues were incubated in neutral
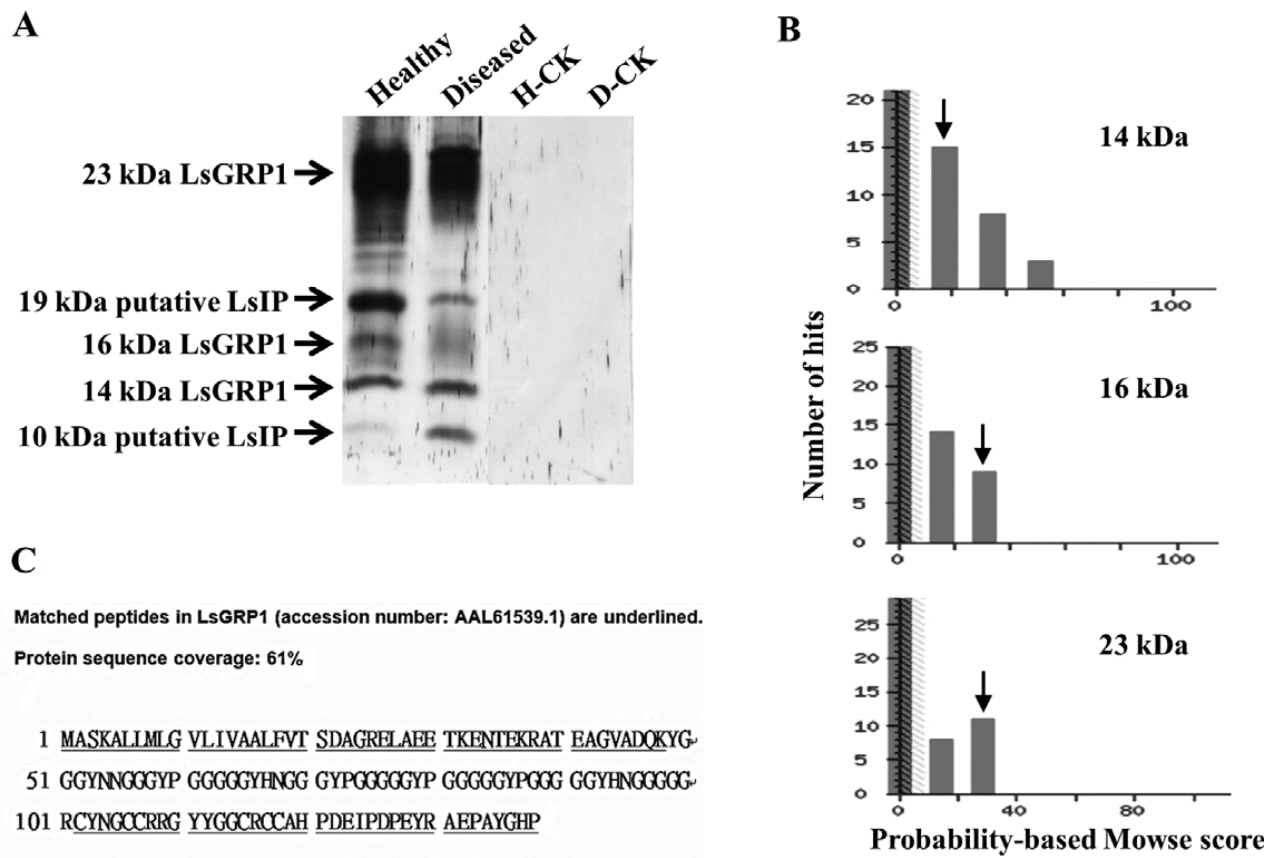

Fig. 2. Identification of LsGRP1 using liquid chromatography-electrospray ionization-tandem mass spectrometry analysis. A, LsGRP1 of 14,16 , and 23 kDa and two putative LsGRP1-interacting proteins (LsIP) of 19 and $10 \mathrm{kDa}$ were isolated from healthy and Botrytis elliptica-infected Stargazer lily leaves 5 days postinoculation using co-immunoprecipitation with LsGRP1 $^{\mathrm{N}}$ antibody and separated using $16 \%$ tricine-sodium dodecyl sulfate-polyacrylamide gel electrophoresis. Proteins were visualized using silver stain. H-CK and D-CK were negative controls for healthy and diseased samples, respectively, and obtained using co-immunoprecipitation with no added LsGRP1 ${ }^{\mathrm{N}}$ antibody. B, The 14-, 16-, and 23-kDa signals that were recognized by LsGRP1 ${ }^{\mathrm{N}}$ antibody were identified as LsGRP1 with probability-based Mowse scores of 21, 22, and 24, respectively, as indicated by an arrow. C, LsGRP1 of 14,16 and $23 \mathrm{kDa}$ had $61 \%$ sequence coverage in the putative amino acid sequence of LsGRP1. 
MOPS buffer to establish the signal present in the cell wall; then, LsGRP1-EGFP signals were observed not only in the plasma membrane but also in the cell wall (Fig. 4). Thus, dual subcellular localization of LsGRP1 in the plasma membrane and the cell wall was verified.

LsGRP1 of $14 \mathrm{kDa}$ is a membrane protein. The plasma membrane-associated feature of LsGRP1 was examined using detergent-assisted extraction because the extraction of most
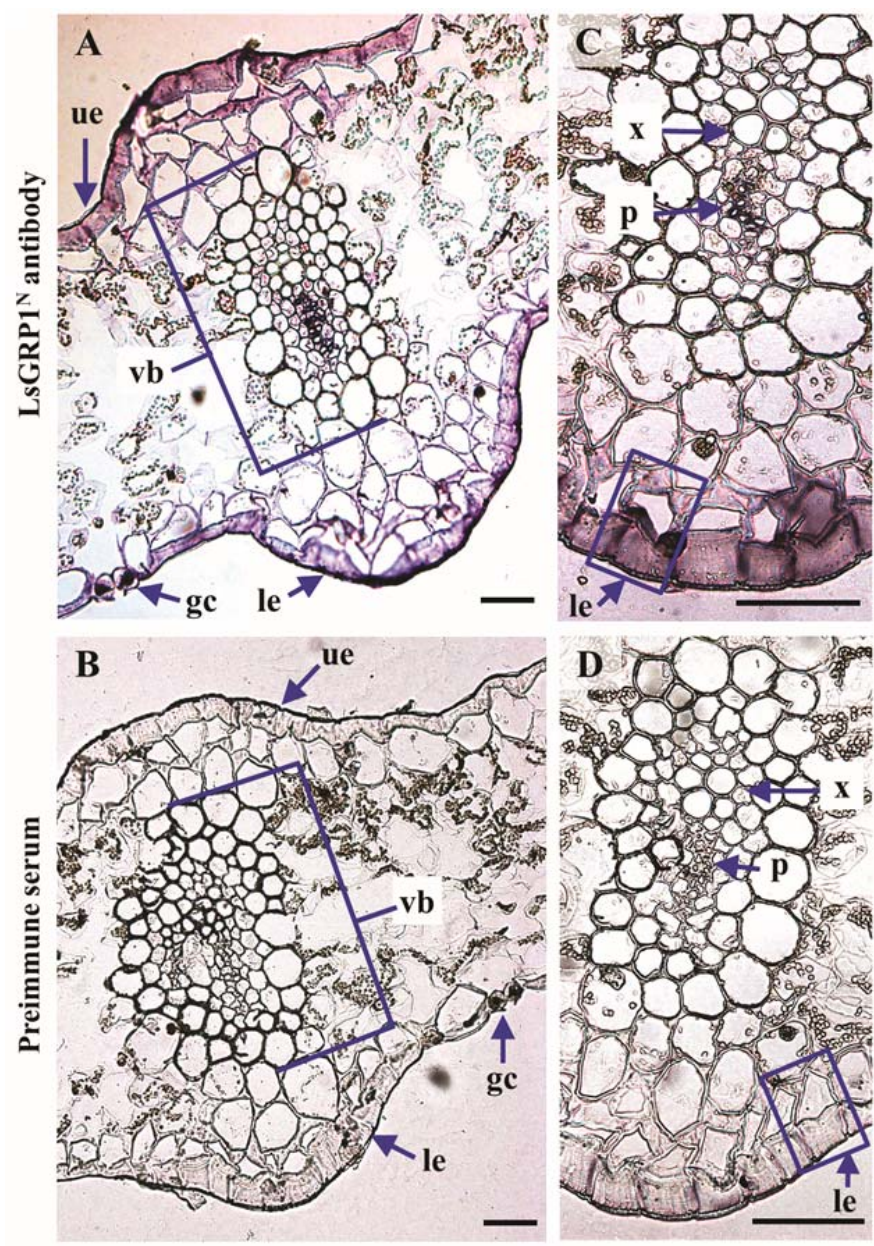

Fig. 3. Immunohistochemical distribution of LsGRP1 in Stargazer lily leaves. The cross-sections of leaf tissues were hybridized with LsGRP1 ${ }^{\mathrm{N}}$ antibody (A and $\mathbf{C}$ ) and preimmune serum $(\mathbf{B}$ and $\mathbf{D})$. Ue = upper epidermis, le = lower epidermis, $\mathrm{gc}=$ guard cell, $\mathrm{vb}=$ vascular bundle, $\mathrm{x}=$ xylem, $\mathrm{p}=$ phloem. Bar $=50 \mu \mathrm{m}$. membrane proteins, especially integral membrane proteins, from biological membranes is normally accomplished with the addition of detergents $(29,31)$. LsGRP1 of 14, 16, and $23 \mathrm{kDa}$ could all be isolated using $1 \%$ Triton X-100 (a mild detergent)-containing EB, but only 16- and 23-kDa LsGRP1 was present in fraction $\mathrm{P}$ (extracted with PBS), which indicated that detergent was not required for the isolation of 16- and 23-kDa LsGRP1 (Fig. 5A). LsGRP1 of $14 \mathrm{kDa}$ was present only in fractions EB, S, and PPS, which indicated that detergents, such as mild detergent Triton X100 and strong detergent SDS, were indispensable for its isolation. Moreover, 14-kDa LsGRP1 was absent in the SPS fraction from the same leaf tissues that had been extracted a second time with $1 \%$ SDS solution. The topology prediction of plasma membrane-localized 14-kDa LsGRP1using the SOSUI ver. 1.11 server showed that the $\mathrm{N}$-terminal signal peptide (1 to 24 amino acids) of LsGRP1 forms a single-pass, hydrophobic, primary transmembrane helix that is not removed after 14-kDa LsGRP1 is targeted to the plasma membrane, and the remaining portion of 14-kDa LsGRP1 is exposed to the extracellular space (Fig. 5B). Thus, it was proposed that $14-\mathrm{kDa}$ LsGRP1 is a signal-anchored type II integral membrane protein (24).

LsGRP1 of 16 and $23 \mathrm{kDa}$ binds weakly to the cell wall. Unlike the detergent-required extraction of plasma membranelocalized 14-kDa LsGRP1, LsGRP1 of 16 and $23 \mathrm{kDa}$ was highly soluble in PBS (fraction P) and scarcely extracted with 1\% SDS solution (fraction S) (Fig. 5A). To examine cell wall-localization of 16- and 23-kDa LsGRP1, Western blot detection of LsGRP1 in the extracts from apoplastic space and isolated cell walls of lily leaf tissues using different salts was performed. Among the apoplastic extracts that were sequentially collected using $\mathrm{NaCl}-$, $\mathrm{CaCl}_{2^{-}}, \mathrm{LiCl}-$, and CDTA-containing acetate buffers, $16-\mathrm{kDa}$ LsGRP1 was only observed in the CDTA extract while 23-kDa LsGRP1 was present in the $\mathrm{NaCl}, \mathrm{CaCl}_{2}, \mathrm{LiCl}$, and CDTA extracts (Fig. 6A). On the other hand, among the extracts of isolated cell walls that were sequentially collected using $\mathrm{CaCl}_{2}$, LiCl-, and CDTA-containing acetate buffers, 16-kDa LsGRP1 was detected in the $\mathrm{CaCl}_{2}$ extract while 23-kDa LsGRP1 was detected in the $\mathrm{CaCl}_{2}$ and $\mathrm{LiCl}$ extracts (Fig. 6B). As predicted, plasma membrane-localized 14-kDa LsGRP1 was absent in these extracts. These results indicated that 16- and 23-kDa LsGRP1 weakly binds to the cell walls of lily leaves.

According to the report by Wagner and Kohorn (39), cell walldegrading enzyme-mediated extractions were used to examine the association of LsGRP1 with cell wall components. The application of pectinase and cellulase significantly increased the recovery of $16-\mathrm{kDa}$ LsGRP1 from pulverized leaf tissues in dose- and time-dependent manners (Fig. 6C). In contrast, the isolation of 23-kDa LsGRP1 was not affected by cell wall-degrading enzyme treatments. As predicted, plasma membrane-localized 14-kDa

TABLE 1. Subcellular localization prediction of LsGRP1 using server ProtComp ver. 9.0

\begin{tabular}{|c|c|c|c|c|c|}
\hline \multirow[b]{2}{*}{ Subcellular location } & \multicolumn{5}{|c|}{ Scores } \\
\hline & $\operatorname{LocDB}^{\mathrm{a}}$ & PotLocDB $^{b}$ & Neural nets ${ }^{\mathrm{c}}$ & Pentamers $^{\mathrm{d}}$ & Integral $^{\mathrm{e}}$ \\
\hline Nuclear & 0.0 & 0.0 & 0.34 & 0.00 & 0.69 \\
\hline Plasma membrane & 0.0 & 3.0 & 0.00 & 2.82 & 4.86 \\
\hline Extracellular & 5.0 & 0.0 & 2.41 & 3.80 & 3.11 \\
\hline Cytoplasmic & 0.0 & 0.0 & 0.00 & 0.00 & 1.00 \\
\hline Mitochondrial & 0.0 & 0.0 & 0.00 & 0.00 & 0.00 \\
\hline Endoplasmic reticulum & 0.0 & 0.0 & 0.00 & 0.98 & 0.00 \\
\hline Peroxisomal & 0.0 & 0.0 & 0.00 & 0.00 & 0.00 \\
\hline Golgi apparatus & 0.0 & 0.0 & 0.25 & 0.00 & 0.34 \\
\hline Chloroplast & 0.0 & 0.0 & 0.00 & 0.00 & 0.00 \\
\hline Vacuolar & 0.0 & 0.0 & 0.00 & 0.00 & 0.00 \\
\hline
\end{tabular}

a Scores based on query protein's homologies with proteins of known localization.

b Scores based on homologies with proteins which locations are not experimentally known but are assumed from strong theoretical evidence.

c Scores assigned by neural networks.

d Scores based on comparisons of pentamer distributions calculated for QUERY and DB sequences.

e Final scores that combine all predicted scores. 
LsGRP1 was absent under these extraction conditions. These results suggested that $16-\mathrm{kDa}$ LsGRP1 might associate with some cell wall components, such as pectins and cellulose.

LsGRP1 ubiquitination is triggered by SA treatment and $B$. elliptica infection. The time modes of LsGRP1 accumulation in response to SA treatment and B. elliptica infection in the middle leaves of 6-week-old lily plants are shown in Figure 7A. After the lily plants were drenched with SA solution, the expression of 14-, 16-, and 23-kDa LsGRP1 was significantly increased at 3 days post treatment $(\mathrm{dpt})$ and became more abundant at $5 \mathrm{dpt}$. Then,

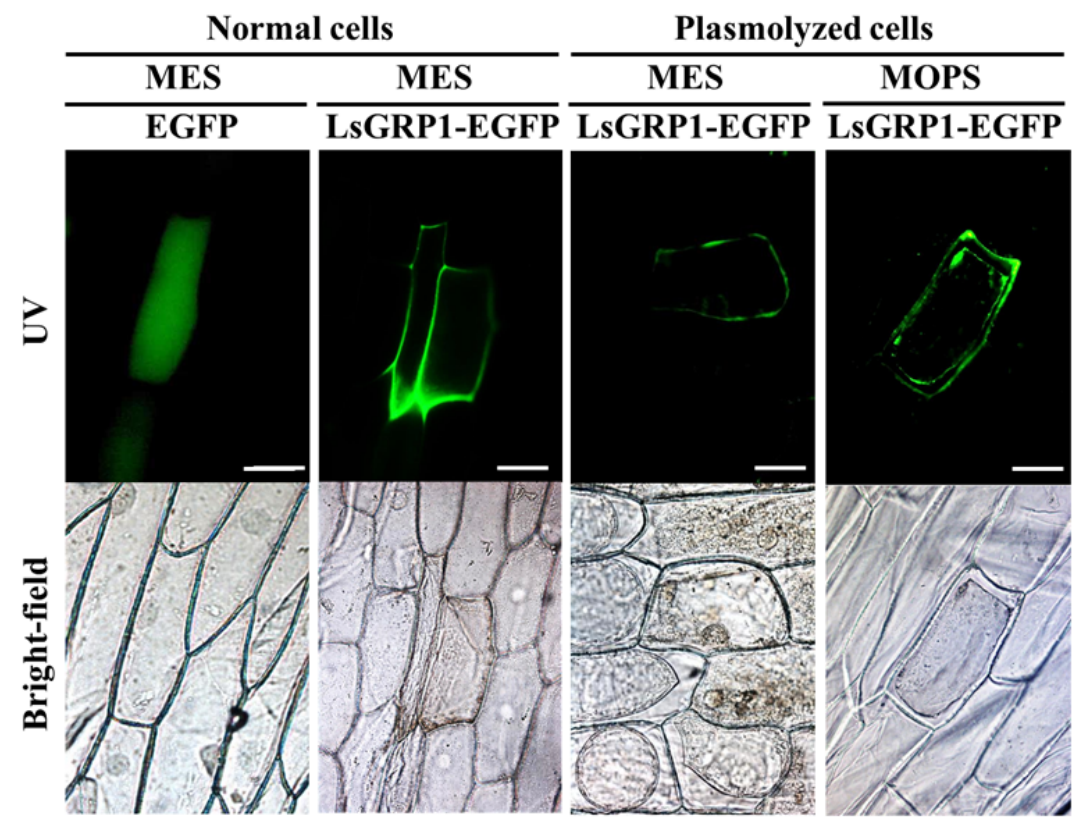

Fig. 4. Subcellular localization of LsGRP1 visualized via the enhanced green fluorescent protein (EGFP) imaging assay. Onion epidermal cells transiently expressing LsGRP1-EGFP or EGFP were incubated in 2-(N-morpholino)ethanesulfonic acid (MES) or 3-(N-morpholino)-propanesulfonic acid (MOPS) buffer for 24 to $48 \mathrm{~h}$ before observation under brightfield and fluorescence (UV) microscopes. The plasmolysis of transformed epidermal cells of onion bulbs was conducted using $2 \mathrm{M} \mathrm{NaCl}$ treatment. Bar $=50 \mu \mathrm{m}$.

A $\mathbf{a}$
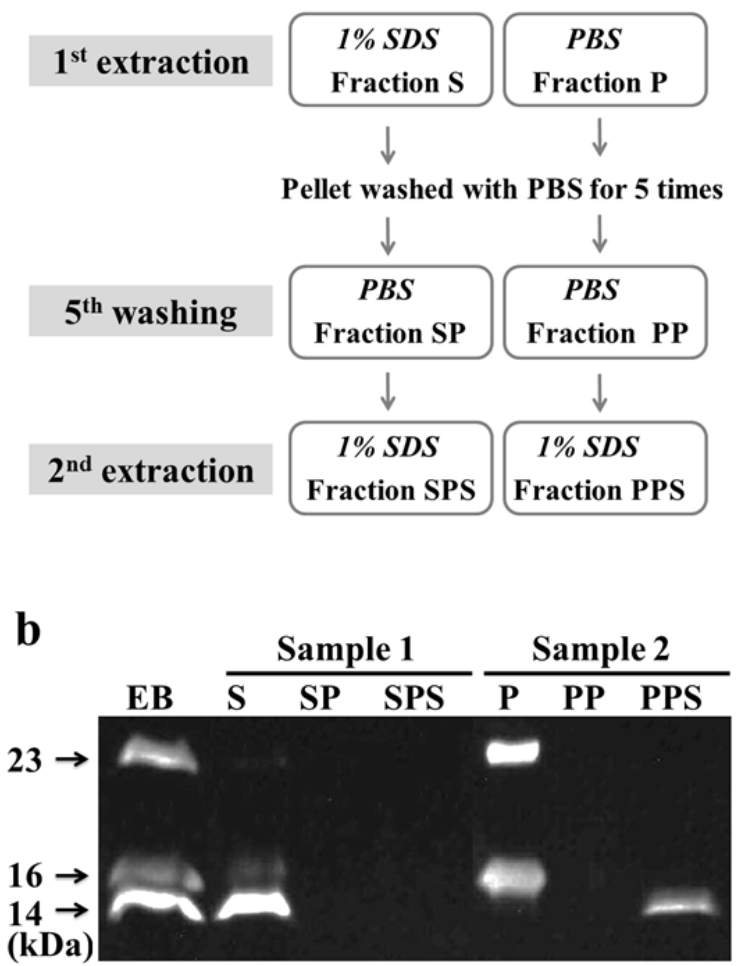

B $\mathbf{a}$

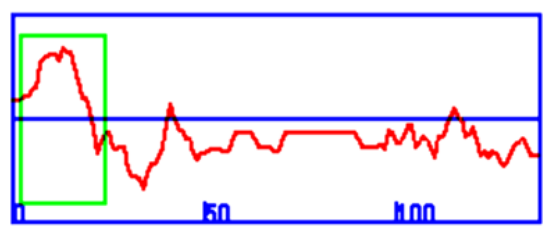

b

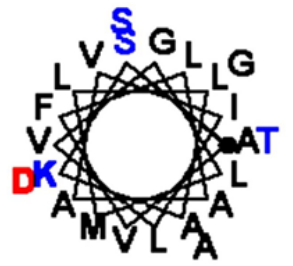

c

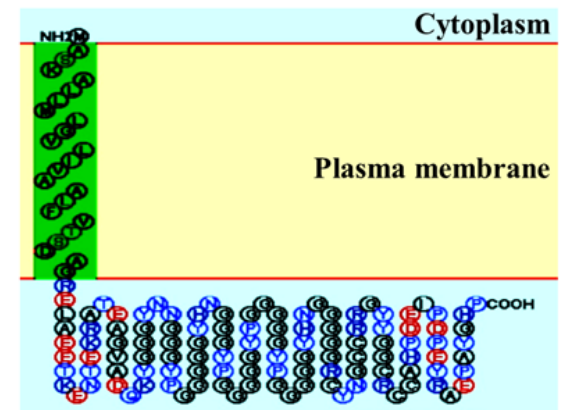

Fig. 5. LsGRP1 of $14 \mathrm{kDa}$ is a membrane protein. A, Detergent-assisted extraction of 14-kDa LsGRP1. a, Procedure of detergent-assisted protein extraction, as outlined from the description in the Materials and Methods; b, Western blot detection of LsGRP1 in different fractions. EB = extraction buffer-extracted leaf protein sample. B, Topology prediction of LsGRP1 using the SOSUI ver. 1.11 server. a, Hydropathy profile of LsGRP1. The putative transmembrane region is demarcated by a rectangle at the N-terminus of LsGRP1. b, Helical wheel diagram of the putative transmembrane region of LsGRP1. c, Putative secondary structure of LsGRP1 with a primary transmembrane helix. 
the amount of 16- and 23-kDa LsGRP1 decreased to the basal level at $7 \mathrm{dpt}$ whereas 14-kDa LsGRP1 remained at a high level. On the other hand, after inoculation with B. elliptica, the amount of $14-$ and $23-\mathrm{kDa}$ LsGRP1 was slightly reduced at 1 dpi but rebounded back to a level similar to that of the control at 3 dpi and became abundant at $5 \mathrm{dpi}$. When the amount of $23-\mathrm{kDa}$
LsGRP1 decreased to the basal level at 7 dpi, the high level of 14-kDa LsGRP1 was maintained. However, 16-kDa LsGRP1 did not significantly accumulate after inoculation with $B$. elliptica.

As assayed by the CKSAAP UbSite server (4), two potential ubiquitination sites were located at the 32nd and 37th lysine residues of LsGRP1 with high confidence (Fig. 7B a). Further-
A

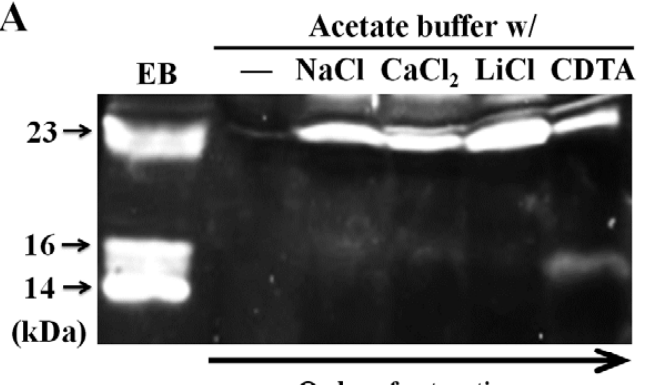

Order of extractions
B

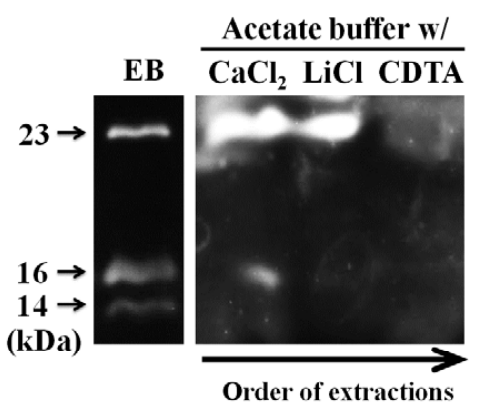

C
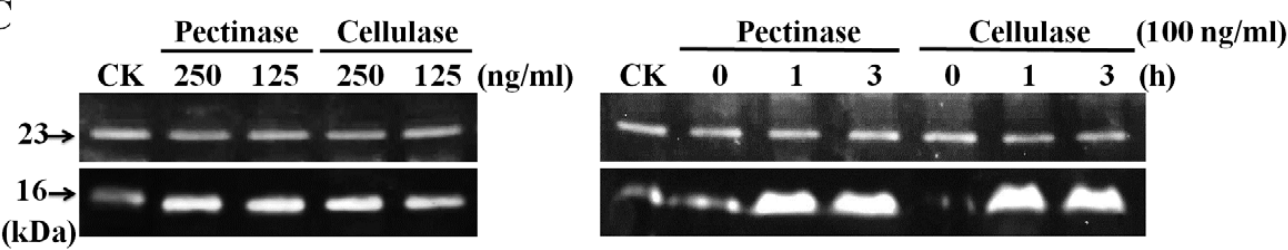

Fig. 6. LsGRP1 of 16 and $23 \mathrm{kDa}$ weakly binds to the cell wall. A, LsGRP1 of 16 and $23 \mathrm{kDa}$ recovered from the apoplastic fluids of lily leaves. Western blot detection of the apoplastic extracts that were sequentially collected using no salt added acetate buffer (-) and $\mathrm{NaCl}_{-}, \mathrm{CaCl}_{2^{-}}, \mathrm{LiCl}_{-}$, and 1,2-diaminocyclohexane tetra acetic acid monohydrate (CDTA)-containing acetate buffers. B, LsGRP1 of 16 and $23 \mathrm{kDa}$ binding to the isolated cell walls of lily leaves. Western blot detection of LsGRP1 from the isolated cell walls that were sequentially collected using $\mathrm{CaCl}_{2^{-}}, \mathrm{LiCl}-$, and CDTA-containing acetate buffers. $\mathbf{A}$ and $\mathbf{B}$, EB = extraction buffer-extracted leaf protein sample. C, Application of cell wall-degrading enzymes facilitated the isolation of 16-kDa LsGRP1. Western blot detection of LsGRP1 in the extracts from lily leaf tissues by incubation with $\mathrm{CaCl}_{2}$ buffer containing pectinase or cellulase at $125 \mathrm{or} 250 \mathrm{ng} / \mathrm{ml}$ for $1 \mathrm{~h}$ (left panel) or CaCl 2 buffer containing pectinase or cellulase at $100 \mathrm{ng} / \mathrm{ml}$ for 0,1 , or $3 \mathrm{~h}$ (right panel). $\mathrm{CK}=$ without enzyme treatment.

A a SA

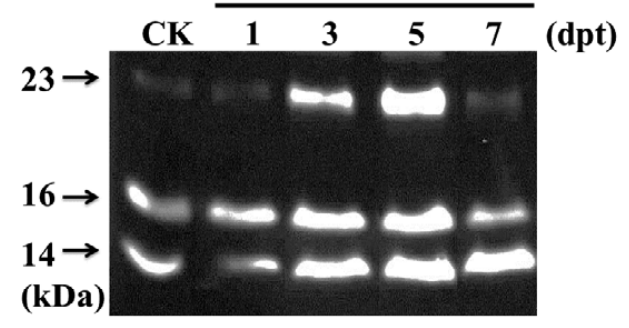

b

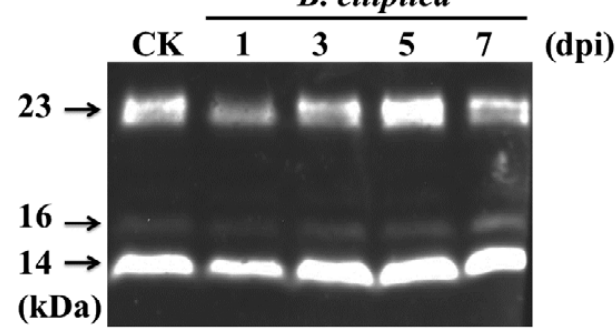

B a

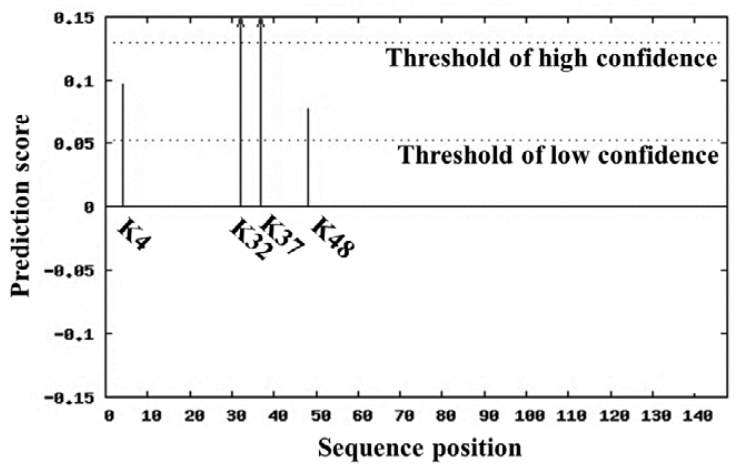

b

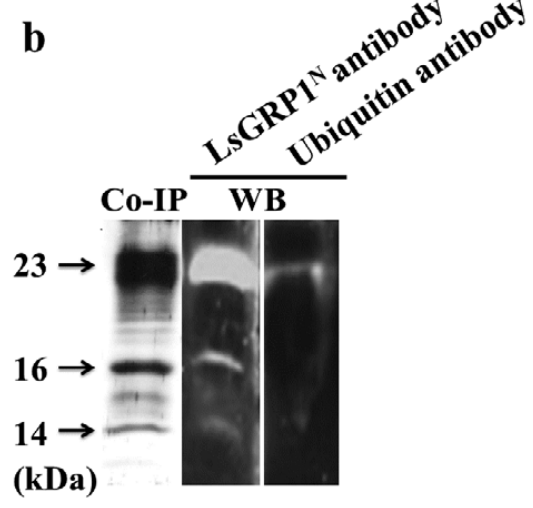

Fig. 7. Increased accumulation and ubiquitination of LsGRP1. A, Time modes of LsGRP1 accumulation in response to a, salicylic acid (SA) treatment or b, Botrytis elliptica infection. $\mathrm{CK}=$ drenched with water (a) or sprayed with $0.05 \%$ Tween- 20 solution (b). B, LsGRP1 of $23 \mathrm{kDa}$ was considered ubiquitinated. a, Prediction of the ubiquitination sites in LsGRP1 using the CKSAAP UbSite server (4). b, Total leaf proteins of Stargazer lily at 5 days post salicylic acid treatment were co-immunoprecipitated (Co-IP) with LsGRP1 ${ }^{\mathrm{N}}$ antibody and assayed by Western blotting (WB) with LsGRP1 ${ }^{\mathrm{N}}$ and ubiquitin antibodies. 
more, the total proteins that were extracted from the lily leaves 5 days after SA treatment or B. elliptica inoculation were subjected to co-immunoprecipitation with $\mathrm{LsGRP}^{\mathrm{N}}$ antibody and analyzed by Western blotting with LsGRP1 $^{\mathrm{N}}$ and ubiquitin antibodies. Interestingly, only $23-\mathrm{kDa}$ LsGRP1 but not $14-$ or $16-\mathrm{kDa}$ LsGRP1 was recognized by the antibody against human ubiquitin, which shares $>90 \%$ sequence identity with Stargazer lily ubiquitin (Stargazer lily ubiquitin sequences based on unpublished transcriptome data) (Fig. 7B b). Thus, 23-kDa LsGRP1 was considered to be ubiquitinated, and its amount increased in response to SA treatment or B. elliptica infection.

\section{DISCUSSION}

Induced resistance in plants is a state involving enhanced defense responses against biotic and abiotic stresses (1,7,33,38). Most plant GRPs exhibit tissue-specificity and are involved in plant defense responses $(23,26,27)$. Some plant class II GRPs have been proven to play a role in disease resistance via proteinprotein interaction $(19,25,35,36,40)$. SA- and B. elliptica-inducible defense-related $L s G R P 1(17,18)$, which encodes a plant class II GRP, was able to reduce disease symptoms and pathogen accumulations in Nicotiana benthamiana and Arabidopsis (unpublished data). In this study, the identification of 14-, 16-, and 23-kDa LsGRP1 using LC-ESI-MS/MS analysis suggested that posttranslational modifications might alter the molecular mass of LsGRP1, and 23-kDa LsGRP1 was presumed to be ubiquitinated, as indicated by its detection by a ubiquitin antibody. Because mono-ubiquitination adds a molecular mass of approximately $8.6 \mathrm{kDa}$ to a ubiquitinated protein (11), it was reasonable to propose that 23-kDa LsGRP1 was derived from mono-ubiquitination of $14-\mathrm{kDa}$ LsGRP1. As is known, ubiquitination regulates a wide variety of cellular processes in eukaryotes, including plant defense signaling and responses $(5,12,13,20)$. The proposed ubiquitination feature of LsGRP1 suggests a role for LsGRP1 in plant defenses and is a new type of posttranslation modification for a plant class II GRP.

In the leaves of lily plants, 14- and 16-kDa LsGRP1 maintained the expression at basal levels at different growth stages but the amount of $23-\mathrm{kDa}$ LsGRP1 was severely decreased at the senescence stage, which is a highly B. elliptica-susceptible period for Stargazer lily based on our observations. In addition, the temporal accumulations of 14- and 23-kDa LsGRP1 in response to SA treatment and B. elliptica infection coincided with the temporal profiles of LsGRPl mRNA, as shown in a previous report (17). Thus, the relationship between proposed ubiquitination of 14-kDa LsGRP1 and plant defense against B. elliptica was assumed. On the other hand, the co-isolation of putative LsIPs of 19 and $10 \mathrm{kDa}$ with LsGRP1 ${ }^{\mathrm{N}}$ antibody from healthy and diseased lily leaves, respectively, suggested that LsGRP1 might be involved in protein-protein interactions, similar to other plant class II GRPs $(19,25,35,36,40)$. Because mono-ubiquitination is capable of altering the abundance, localization, protein-protein interaction, and functions of membrane proteins $(9,11,30)$, the proposed ubiquitination of LsGRP1 might be related to its subcellular localization, protein-protein interaction, and defense activation, which required further investigation.

Because the in vivo distribution of LsGRP1 was predominantly in the plasma membrane and the cell walls of epidermal and phloem tissues, LsGRP1 is likely to play a role in the first line of defense against $B$. elliptica infection. The in vitro inhibitory activity of the LsGRP1-derived peptide $\operatorname{LsGRP1} 1^{\mathrm{C}}$ on different types of phytopathogenic microorganisms via alteration of microbial membrane permeability and induction of fungal programmed cell death-like phenomena, and the presence of LsGRP1 ${ }^{\mathrm{C}}$ on the cell surface of various fungal species, including B. elliptica, have been demonstrated (14). The C-terminus of LsGRP1 that is exposed to the extracellular matrix might function in directly delaying the invasion of $B$. elliptica or recognizing the cell surface components of $B$. elliptica to trigger fungal cell death progress.

For the extraction of weakly bound cell wall proteins, $\mathrm{NaCl}$ is usually used to isolate ionic interaction-retaining proteins while $\mathrm{CaCl}_{2}$ is likely most efficient in selectively solubilizing proteins that are weakly bound to the polysaccharides of the cell wall $(2,8,32)$. In addition, $\mathrm{LiCl}$ can assist in the isolation of certain hydroxyproline-rich glycoproteins and CDTA, which is a chelating agent, is able to solubilize $\mathrm{Ca}^{2+}$-pectate and release a small amount of proteins containing polysaccharide-interacting domains $(2,8,32)$. Thus, according to the result of sequential extraction of apoplastic proteins using $\mathrm{NaCl}-, \mathrm{CaCl}_{2^{-}}, \mathrm{LiCl}-$, and CDTAcontaining acetate buffers, the cell wall-binding strength of $16-\mathrm{kDa}$ LsGRP1 should be stronger than that of 23-kDa LsGRP1. However, the co-release of 16- and 23-kDa LsGRP1 from the isolated cell walls with $\mathrm{CaCl}_{2}$-containing acetate buffer revealed that pulverization of the cell wall structure facilitated the release of $16-\mathrm{kDa}$ LsGRP1. Moreover, the results of cell wall-degrading enzyme-mediated extractions suggested the association of 16-kDa LsGRP1 with cell wall components. Because the strength and composition of cell walls might influence the extraction efficiency of 16-kDa LsGRP1, an inconsistency in the extraction yield of $16-\mathrm{kDa}$ LsGRP1 occurred. The lateral diffusion of membrane proteins from the plant membrane is mainly constrained by the cell wall, which is composed of a cellulose microfibril meshwork and cell wall-associated components such as pectins and hemicelluloses (21). Therefore, 16-kDa LsGRP1 might be an intermediate during the conversion of plasma membrane-anchored 14-kDa LsGRP1 to cell wall-bound 23-kDa LsGRP1 or a specified LsGRP1 that is immobilized in the extracellular matrix or at the interface of the plasma membrane and the cell wall.

In summary, the key features of LsGRP1 were characterized in this study and the involvement of LsGRP1 in disease resistance was proposed via mono-ubiquitination, a novel trait that has not been previously disclosed for a plant class II GRP. The dual subcellular localization and protein interactions of LsGRP1 most likely contribute to the increased disease resistance in lily plants in a way that is not yet fully understood.

\section{ACKNOWLEDGMENTS}

This study was financially supported by the National Science Council, Taiwan, Republic of China.

\section{LITERATURE CITED}

1. Bostock, R. M. 1999. Signal conflicts and synergies in induced resistance to multiple attackers. Physiol. Mol. Plant Pathol. 55:99-109.

2. Boudart, G., Jamet, E., Rossignol, M., Lafitte, C., Borderies, G., Jauneau, A., Esquerré-Tugayé, M. T., and Pont-Lezica, R. 2005. Cell wall proteins in apoplastic fluids of Arabidopsis thaliana rosettes: Identification by mass spectrometry and bioinformatics. Proteomics 5:212-221.

3. Chen, C. Y., Lu, Y. Y., and Chung, J. C. 2003. Induced host resistance against Botrytis leaf blight. Page 259-267 in: Advances in Plant Disease Management. Research Signpost, Trivandrum, Kerala, India.

4. Chen, Z., Chen, Y. Z., Wang, X. F., Wang, C., Yan, R. X., and Zhang, Z. 2011. Prediction of ubiquitination sites by using the composition of $k$ spaced amino acid pairs. PLoS One 6:e22930.

5. Devoto, A., Muskett. P. R., and Shirasu, K. 2003. Role of ubiquitination in the regulation of plant defence against pathogens. Curr. Opin. Plant Biol. 6:307-311.

6. Doss, R. P., Chastagner, G. A., and Riley, K. I. 1988. Streaking of lily leaves associated with infection by Botrytis elliptica. Plant Dis. 72:859861.

7. Durrant, W. E., and Dong, X. 2004. Systemic acquired resistance. Annu. Rev. Phytopathol. 42:185-209.

8. Feiz, L., Irshad, M., Pont-Lezica, R. F., Canut, H., and Jamet, E. 2006. Evaluation of cell wall preparations for proteomics: A new procedure for purifying cell walls from Arabidopsis hypocotyls. Plant Methods 2:10.

9. Guerra, D. D., and Callis, J. 2012. Ubiquitin on the move: The ubiquitin modification system plays diverse roles in the regulation of endoplasmic 
reticulum- and plasma membrane-localized proteins. Plant Physiol. 160:56-64.

10. Haupts, U., Maiti, S., Schwille, P., and Webb, W. W. 1998. Dynamics of fluorescence fluctuations in green fluorescent protein observed by fluorescence correlation spectroscopy. Proc. Natl. Acad. Sci. USA 95:13573-13578.

11. Hicke, L. 2001. Protein regulation by monoubiquitin. Nat. Rev. Mol. Cell Biol. 2:195-201.

12. Lee, D. H., Choi, H. W., and Hwang, B. K. 2011. The pepper E3 ubiquitin ligase RING1 gene, CaRING1, is required for cell death and the salicylic acid-dependent defense response. Plant Physiol. 156:2011-2025.

13. Li, W., Ahn, I. P., Ning, Y., Park, C. H., Zeng, L., Whitehill, J. G. A., Lu, H., Zhao, Q., Ding, B., Xie, Q., Zhou, J.-M., Dai, L., and Wang, G. L. 2012. The U-Box/ARM E3 ligase PUB13 regulates cell death, defense, and flowering time in Arabidopsis. Plant Physiol. 159:239-250.

14. Lin, C. H., Chang, M. W., and Chen, C. Y. 2014. A potent antimicrobial peptide derived from the protein LsGRP1 of Lilium. Phytopathology 104:340-346.

15. López-Millán, A. F., Morales, F., Abadía, A., and Abadía, J. 2000. Effects of iron deficiency on the composition of the leaf apoplastic fluid and xylem sap in sugar beet. Implications for iron and carbon transport. Plant Physiol. 124:873-884.

16. Lu, Y. Y., and Chen, C. Y. 1998. Probenazole-induced resistance of lily leaves against Botrytis elliptica. Plant Pathol. Bull. 7:134-140.

17. Lu, Y. Y., and Chen, C. Y. 2005. Molecular analysis of lily leaves in response to salicylic acid effective towards protection against Botrytis elliptica. Plant Sci. 169:1-9.

18. Lu, Y. Y., Liu, Y. H., and Chen, C. Y. 2007. Stomatal closure, callose deposition, and increase of LsGRP1-corresponding transcript in probenazole-induced resistance against Botrytis elliptica in lily. Plant Sci. 172:913-919.

19. Mangeon, A., Junqueira, R. M., and Sachetto-Martins, G. 2010. Functional diversity of the plant glycine-rich proteins superfamily. Plant Signal. Behav. 5:99-104.

20. Marino, D., Peeters, N., and Rivas, S. 2012. Ubiquitination during plant immune signaling. Plant Physiol. 160:15-27.

21. Martinière, A., Lavagi, I., Nageswaran, G., Rolfe, D. J., ManetaPeyret, L., Luu, D. T., Botchway, S. W., Webb, S. E. D., Mongrand. S., Maurel, C., Martin-Fernandez, M. L., Kleine-Vehn, J., Friml, J., Moreau, P., and Runions, J. 2012. Cell wall constrains lateral diffusion of plant plasma-membrane proteins. Proc. Natl. Acad. Sci. USA 109:1280512810 .

22. McRae, E. A. 1987. Lily Disease Handbook. The North American Lily Society Press, Geneva, NY.

23. Mousavi, A., and Hotta, Y. 2005. Glycine-rich proteins: A class of novel proteins. Appl. Biochem. Biotechnol. 120:169-174.

24. Ott, C. M., and Lingappa, V. R. 2002. Integral membrane protein biosynthesis: Why topology is hard to predict. J. Cell Sci. 115:2003-2009.
25. Park, A. R., Cho, S. K., Yun, U. J., Jin, M. Y., Lee, S. H., SachettoMartins, G., and Park, O. K. 2001. Interaction of the Arabidopsis receptor protein kinase Wak1 with a glycine-rich protein, AtGRP-3. J. Biol. Chem. 276:26688-26693.

26. Ringli, C., Keller, B., and Ryser, U. 2001. Glycine-rich proteins as structural components of plant cell walls. Cell. Mol. Life Sci. 58:14301441.

27. Sachetto-Martins, G., Franco, L. O., and de Oliveira, D. E. 2000. Plant glycine-rich proteins: A family or just proteins with a common motif? Biochim. Biophys. Acta 1492:1-14.

28. Schägger, H. 2006. Tricine-SDS-PAGE. Nat. Protocols 1:16-22.

29. Schimerlik, M. I. 2001. Overview of membrane protein solubilization. Curr. Protocols Neurosci. doi:10.1002/0471142301.ns0509s02

30. Schnell, J. D., and Hicke, L. 2003. Non-traditional functions of ubiquitin and ubiquitin-binding proteins. J. Biol. Chem. 278:35857-35860.

31. Seddon, A. M., Curnow, P., and Booth, P. J. 2004. Membrane proteins, lipids and detergents: Not just a soap opera. Biochim. Biophys. Acta 1666:105-117.

32. Soares, N. C., Francisco, R., Ricardo, C. P., and Jackson, P. A. 2007. Proteomics of ionically bound and soluble extracellular proteins in Medicago truncatula leaves. Proteomics 7:2070-2082.

33. Sticher, L., Mauch-Mani, B., and Métraux, J. P. 1997. Systemic acquired resistance. Annu. Rev. Phytopathol. 35:235-270.

34. Sun, W., Cao, Z., Li, Y., Zhao, Y., and Zhang, H. 2007. A simple and effective method for protein subcellular localization using Agrobacterium-mediated transformation of onion epidermal cells. Biologia 62:529-532.

35. Ueki, S., and Citovsky, V. 2002. The systemic movement of a tobamovirus is inhibited by a cadmium-ion-induced glycine-rich protein. Nat. Cell Biol. 4:478-485.

36. Ueki, S., and Citovsky, V. 2005. Identification of an interactor of cadmium ion-induced glycine-rich protein involved in regulation of callose levels in plant vasculature. Proc. Natl. Acad. Sci. USA 102:1208912094.

37. Van Larebeke, N., Engler, G., Holsters, M., Van den Elsacker, S., Zaenen, I., Schilperoort, R. A., and Schell, J. 1974. Large plasmid in Agrobacterium tumefaciens essential for crown gall-inducing ability. Nature 252:169-170.

38. Van Loon, L. C., Bakker, P. A. H. M., and Pieterse, C. M. J. 1998. Systemic resistance induced by rhizosphere bacteria. Annu. Rev. Phytopathol. 36:453-483.

39. Wagner, T. A., and Kohorn, B. D. 2001. Wall-associated kinases are expressed throughout plant development and are required for cell expansion. Plant Cell 13:303-318.

40. Yang, E. J., Oh, Y. A., Lee, E. S., Park, A. R., Cho, S. K., Yoo, Y. J., and Park, O. K. 2003. Oxygen-evolving enhancer protein 2 is phosphorylated by glycine-rich protein 3/wall-associated kinase 1 in Arabidopsis. Biochem. Biophys. Res. Commun. 305:862-868. 